NBER WORKING PAPER SERIES

\title{
DO STATE EXPENDITURES ON TOBACCO CONTROL PROGRAMS DECREASE USE OF TOBACCO PRODUCTS AMONG COLLEGE STUDENTS?
}

\author{
Christina Czart Ciecierski \\ Pinka Chatterji \\ Frank J. Chaloupka \\ Henry Weschler \\ Working Paper 12532 \\ http://www.nber.org/papers/w12532
}

\author{
NATIONAL BUREAU OF ECONOMIC RESEARCH \\ 1050 Massachusetts Avenue \\ Cambridge, MA 02138 \\ September 2006
}

The data on student smoking behavior was collected under grants from the Robert Wood Johnson Foundation to Henry Wechsler. The authors would like to thank Nancy A. Rigotti for formulating the smoking questions. The authors also would like to thank Karen Conway, Reagan Baughman, and other participants at an economics department seminar at the University of New Hampshire at Durham in May 2006 for very helpful feedback on a preliminary version of the paper. Chatterji gratefully acknowledges research support from grant K01 AA000328-03 from the National Institute of Alcohol Abuse and Alcoholism. Ciecierski gratefully achnowledges research support from the Robert Wood Johnson Foundation through ImpacTeen. The views expressed herein are those of the author(s) and do not necessarily reflect the views of the National Bureau of Economic Research.

(O2006 by Christina Czart Ciecierski, Pinka Chatterji, Frank J. Chaloupka and Henry Weschler. All rights reserved. Short sections of text, not to exceed two paragraphs, may be quoted without explicit permission provided that full credit, including $\odot$ notice, is given to the source. 
Do State Expenditures on Tobacco Control Programs Decrease Use of Tobacco Products Among College Students?

Christina Czart Ciecierski, Pinka Chatterji, Frank J. Chaloupka and Henry Weschler

NBER Working Paper No. 12532

September 2006

JEL No. I1

\begin{abstract}
The objective of this paper is to investigate the effects of state tobacco control program expenditures on individual-level tobacco use behaviors among young adults. Data come from the 1993, 1997, 1999 and 2001 waves of the Harvard School of Public Health College Alcohol Study (CAS). Our findings indicate that a higher level of state spending on tobacco control programs is associated with a statistically significant increase in the probability that smokers report at least one attempt to quit smoking in the past year, as well as increases in the number of attempts to quit in the past year among smokers. We also find that higher state expenditures on tobacco control programs are associated with reductions in the prevalence of smokeless tobacco and cigar use among college students. We do not find, however, any statistically significant association between state tobacco control program expenditures and the overall prevalence and intensity of cigarette use among college students, a finding that is at odds with previous research on high school students.
\end{abstract}

\author{
Christina Czart Ciecierski \\ University of Illinois at Chicago \\ Institute for Health Research and Policy \\ School of Public Health \\ 1747 W. Roosevelt Road, M/C 275 \\ Chicago, IL. 60608 \\ cczart1@uic.edu \\ Pinka Chatterji \\ Center for Multicultural Mental Health \\ Research \\ Cambridge Health Alliance \\ Harvard Medical School \\ 120 Beacon Street, $4^{\text {th }}$ Floor \\ Somerville, MA 02143 \\ and NBER \\ pchatterji@charesearch.org
}

\author{
Frank J. Chaloupka \\ University of Illinois \\ Department of Economics \\ College of Business Administration \\ 601 South Morgan Street, Room 2103 \\ Chicago, IL 60607-7121 \\ and NBER \\ fjc@uic.edu
}

Henry Wechsler

Harvard School of Public Health

677 Huntington Avenue

Boston, MA 02115

hwechsle@hsph.harvard.edu 


\subsection{Introduction and Background}

Over the past decade, there have been appreciable declines in the use of tobacco products among young people. In 1997, when adolescent smoking rates were at their peak for the 1990's, 36.5 percent of high school seniors reported using cigarettes in the past 30 days and 9.7 percent reported using smokeless tobacco in the past 30 days but, by 2005, these rates had fallen to 23.2 percent for cigarettes and 7.6 percent for smokeless tobacco (1). The prevalence of tobacco use among young adults also started to decline during this time period, but less dramatically. Among college students, the past month prevalence of cigarette use increased from 22.2 to 28.2 percent between 1993 and 1997. Subsequently, smoking rates among college students declined somewhat, falling to about 25 percent by 2001(2). ' Similarly, between 1993 and 2001, college students' past 30 day use of smokeless tobacco fell from 4.6 percent to 3.2 percent (2). In the 18 to 24 year old age group more generally, data from the National Health Interview Survey show that in 2004, 23.6 percent of this age group reported current smoking ${ }^{2}$, a 14 percent decline from 1994 when this rate was 27.5 percent $(3,4)$. Current use of smokeless tobacco ${ }^{3}$ among 18 to 24 year old adults in the NHIS declined from 7.7 percent to 5.0 percent between 1994 and 2000 (5).

While this progress is encouraging, the rate of smoking among young adults in 2004 was still almost twice as high as the Healthy People 2010 target of 12 percent (6). Moreover, it is alarming that large numbers of young people continue to smoke and use smokeless tobacco, despite overwhelming evidence that these behaviors are potentially

\footnotetext{
${ }^{1}$ Young adult smoking rates would be expected to begin to fall a few years after the decline in teenage smoking because of cohort effects, holding other factors constant.

${ }^{2}$ Defined as smoking at least 100 cigarettes in lifetime and at time of interview smoked every day or some days.

${ }^{3}$ Defined as using at least 20 times in lifetime as well as current use (in 1994 NHIS) or using every day or some days (in 2000 NHIS).
} 
deadly. Smoking causes numerous types of cancer, cardiovascular disease, and respiratory diseases, and it remains the single, most important factor underlying preventable death and disease in the US $(6,7)$. Use of smokeless tobacco has been linked to cancers and lesions of the mouth as well as nicotine addiction (8). Quitting smoking has important and immediate health benefits for people of all ages, including a reduction in the risk of developing cancer, heart attack, stroke and chronic lung disease $(9,10)$.

Given the large numbers of young tobacco users in the United States, the known health consequences of these risky behaviors, and the demonstrated benefits of quitting, there is considerable interest in state-level policies that can decrease youths' consumption of tobacco products. Existing research supports the idea that state policies are effective tools that can be used to raise the full price of smoking (either by increasing the money price, the time price, or both) and thus reduce smoking among teenagers and young adults $(6,11)$. Increasing the price of cigarettes has been linked to decreases in smoking prevalence among high school and college age youth as well as reductions in daily smoking, frequency of smoking, average consumption, and smoking initiation among young people (12-14). Other state tobacco control policies, such as clean indoor air laws and youth access limits, also have been shown to be effective in reducing smoking among youth. A smaller body of research indicates that public policies also are effective in reducing rates of smokeless tobacco use (14-17).

An additional, less-studied mechanism through which states potentially can influence youth tobacco use is large-scale, comprehensive tobacco control programs. Currently, all states and the District of Columbia fund such programs, which tend to be diverse and multi-faceted. The Centers for Disease Control and Prevention (CDC) recently published best practice guidelines for comprehensive state tobacco control programs, with recommendations for funding ranges and program components (18). 
These guidelines indicate that a comprehensive tobacco control program should include the following: community-based interventions to reduce tobacco use, chronic disease programs to decrease the burden of tobacco-related illnesses, school programs, enforcement, state-wide programs, counter-marketing, cessation programs, education, surveillance and research, and administration (18). The CDC based these guidelines on the experiences of several states that had initiated and evaluated tobacco control programs early on, including California, Florida, Massachusetts, and Oregon. California, for example, started a state-wide tobacco control program in 1990, using funds from a 25 cent increase in cigarette excise taxes (19). The California Tobacco Control Program was considered a model for other states, and included a media campaign, smoking cessation services, and prevention programming aimed at children and young adults (20) .

State tobacco control programs potentially can change attitudes about tobacco, prevent tobacco use initiation, encourage users to quit or reduce the frequency of use, and, in these ways, ultimately reduce the prevalence of tobacco use among youth. A number of state-level evaluations of tobacco control programs suggest that the programs indeed are associated with declines in tobacco use (21-25). Most state-level evaluations (Hu et al is an exception) rely on a "before/after" study design. In these analyses, therefore, the possibility remains that reductions in tobacco use may have been caused not by tobacco control programs but by other confounding, concurrent factors, such as increases in cigarette excise taxes (19).

Three recent studies address this design issue by utilizing national data instead of data from a single state. The use of national data allows researchers to take into account the effects of other tobacco related policies on tobacco use, as well as include state fixed effects and time trends in models, all of which are helpful in capturing potentially confounding correlates of smoking and tobacco control program expenditures. These 
studies demonstrate that higher state-level expenditures on tobacco control programs are associated with reductions in total, aggregate cigarette sales as well as reductions in selfreported smoking and more negative attitudes about smoking among adolescents $(19,26$, 27) . Farrelly et al.(19), for example, estimate demand models of per capita cigarette sales for the time period 1981 to 2000 . The main covariate of interest is a measure of state expenditures on tobacco control programs (in alternative specifications, the authors use current annual expenditures, lagged annual expenditures, and cumulative expenditures), and the models also include cigarette excise taxes, other time-varying state characteristics, state fixed effects, and time trends. The results consistently show that state spending on tobacco control programs is associated with lower levels of aggregate per capita cigarette sales.

Tauras et al.(26) and Tauras \& Chaloupka (27) build on this study by exploring the individual smoking behaviors and attitudes underlying these aggregate effects. These two studies focus on adolescents, and estimate the effect of state tobacco control expenditures on self-reported smoking (26) and attitudes about smoking (27) using nationally representative data on high school students collected between 1991 and 2000. They report that higher state expenditures on tobacco control programs are associated with lower prevalence and intensity of self-reported teenage smoking, as well as higher levels of negative beliefs about smoking. Thus, these three studies support the idea that tobacco control expenditures are effective, at least in reducing aggregate cigarette sales and in influencing attitudes and demand for cigarettes among adolescents.

The present study continues to investigate the effects of state tobacco control program expenditures on individual-level tobacco use behaviors. We build on prior work by studying the effects of expenditures not just on the prevalence/intensity of smoking, but also on two outcomes that have not been examined: attempts to quit smoking and the 
use of smokeless tobacco and cigars. In addition, we build on previous research by examining the effectiveness of state tobacco control program expenditures in a demographic group that has not been studied to date -- young adults across American college campuses. Data come from the 1993, 1997, 1999 and 2001 waves of the Harvard School of Public Health College Alcohol Study (CAS).

It is critical to study the effects of tobacco control program expenditures on college students' tobacco use behaviors for several reasons. First, the college campus represents a setting where the importance of community health is emphasized. Although tobacco use behaviors are often perceived as personal or individual issues, the college campus forms a specific environment that impacts not only the individual behaviors of students but also allows students to influence each other's behavioral choices, leading to shared health challenges and benefits for the entire campus.

Furthermore, the mechanism linking tobacco control programs to tobacco use may be quite different for college students compared to that of high school students. Unlike younger adolescents, college age youth have long passed the stage of smoking initiation (28), which generally occurs by eighth grade (29). In the CAS sample used in this paper, for example, less than 5 percent of respondents reported initiating smoking after age 18. Compared to older smokers, however, college-age smokers still may be transitioning into regular smoking patterns (28) and they are more likely to be able to quit smoking (30). As a result, tobacco control efforts may be most effective among college students by motivating and providing resources to help current tobacco users quit or reduce consumption. Ultimately, these efforts may lead to changes in the prevalence and intensity of tobacco use driven by individuals quitting or failing to transition into an established pattern of smoking rather than by individuals avoiding or delaying initiation. 
Our findings indicate that state tobacco control expenditures do affect patterns of tobacco use among college students. A higher level of state spending on tobacco control programs is associated with a statistically significant increase in the probability that smokers report at least one attempt to quit smoking in the past year, as well as increases in the number of attempts to quit in the past year among smokers. We also find that higher state expenditures on tobacco control programs are associated with reductions in the prevalence of smokeless tobacco and cigar use among college students. This is the first evidence based on national data that state tobacco control programs are effective in increasing smoking cessation attempts, and decreasing smokeless tobacco and cigar use among young people. We do not find, however, any statistically significant association between state tobacco control program expenditures and the overall prevalence and intensity of cigarette use among college students, a finding that is at odds with previous research on high school students. The increases in attempts to quit among smokers that we observe now, however, ultimately may reduce the prevalence of smoking as these college students age.

\subsection{Empirical Approach}

The aim of the study is to estimate the association between state-level expenditures on tobacco control programs and a range of individual-level smokingrelated outcomes among college students. Our general specification is the following:

$$
\left.\mathrm{S}_{\mathrm{ijkt}}=\delta_{0}+\delta_{1} \mathrm{~T}_{\mathrm{kt}}+\delta_{2} \mathrm{P}_{\mathrm{kt}}+\delta_{3} \mathrm{Y}_{\mathrm{jt}}+\delta_{4} \mathrm{Z}_{\mathrm{it}}+\delta_{5} \gamma_{\mathrm{k}}+\delta_{6} \mu_{\mathrm{t}}+\varepsilon \text {. (Eq. } 1\right)
$$

Equation (1) specifies that the tobacco-related outcome (S) for each student (i) at college (j) in a state $(\mathrm{k})$ at a point in time $(\mathrm{t})$ is a function of: state tobacco control program expenditures $\left(\mathrm{T}_{\mathrm{kt}}\right)$; other state policies related to cigarettes, such as excise taxes $\left(\mathrm{P}_{\mathrm{kt}}\right)$; college characteristics, including smoking policies such as on-campus smoking bans $\left(\mathrm{Y}_{\mathrm{jt}}\right)$; individual-level student characteristics $\left(\mathrm{Z}_{\mathrm{it}}\right)$, state fixed effects $\left(\gamma_{\mathrm{k}}\right)$, year effects 
$\left(\mu_{t}\right)$, and an error term. The main coefficient of interest is $\delta_{1}$, which captures the association between state-level program expenditures on tobacco control and tobacco use outcomes.

In estimating Equation 1, two important issues arise. The first is the nature of the dependent variable. We consider the following classes of tobacco use outcomes: 1) prevalence of tobacco use, captured by three measures of whether or not the respondent currently uses tobacco (any use of cigarettes in past 30 days, any use of smokeless tobacco in past 30 days, any use of cigars in past 30 days); 2) intensity of tobacco use, measured by the number of cigarettes smoked per day, among those who have smoked cigarettes in the past 30 days (this intensity measure is not available for the smokeless tobacco and cigar outcomes); and 3) attempts to quit tobacco use, measured by whether the respondent has made any attempt to quit smoking and the number of quit attempts in the past year among current smokers (quit attempts information is not available for the smokeless tobacco and cigar outcomes). These measures are described in detail below.

In cases of continuous dependent variables (e.g., log of number of cigarettes per day) we use Ordinary Least Squares (OLS) for estimation. In cases of limited dependent variables, we use alternative estimation methods. For binary outcomes (e.g., at least one attempt to quit in past year), we use standard probit models. For models in which the dependent variables is a count of events (e.g., number of attempts to quit in past year), a Poisson or a negative binomial distribution best describes the nature of the dependent variable (31). In our case, the negative binomial distribution is chosen because in likelihood ratio tests based on the number of quits models, we consistently reject the null hypothesis that the underlying distribution is Poisson. For all outcomes, the models are estimated with Huber-White standard errors adjusted for clustering at the state level.

The second estimation issue involves the inclusion of $\gamma_{\mathrm{k}}$, the fixed effects which 
represent the state in which the respondent attends college. Including state fixed effects in the model has both advantages and disadvantages. The advantage of including state fixed effects is that we can account for time-invariant state sentiment that may confound an observed association between state-level tobacco policies and individual-level tobacco use behaviors. For example, states with high levels of anti-smoking sentiment may spend relatively more than other states on tobacco control, as well as have college students who smoke less and are more likely to try to quit smoking compared to students in other states. Including state fixed effects is one way to control for this potential confounding.

The disadvantage of including state fixed effects, however, is that doing so limits the variation in tobacco control program expenditures (as well as cigarette prices and other state specific covariates) to the within state variation in these variables. If there is very limited variation within states over time in any of these state specific covariates, we may not be able to obtain meaningful results. Our data span a relatively short time period (1993 - 2001). Although there appears to be adequate within-state variation in tobacco control program expenditures during these years, it still may not be reasonable to expect within-state changes in program expenditures during this short time period to effect appreciable changes in outcomes, particularly tobacco prevalence outcomes (cessation behaviors may be easier to influence).

Because of these pros and cons of including state fixed effects in the models, we show results from four alternative specifications which include: no geographic indicators; state fixed effects; dummy indicators for region; or a dummy variable indicating the state is a major tobacco producer. The first approach makes no attempt to account for state sentiment towards tobacco. The second approach controls for fixed, unobserved sentiments towards smoking at the state level. The latter two approaches capture sentiment towards smoking at a broader geographic level, allowing for greater "within" 
variation over time in tobacco control program expenditures compared to when state effects are included.

As in any non-experimental study, even when we include state fixed effects, we cannot definitively conclude that an observed association between state tobacco program expenditures and college students' tobacco outcomes reflects a causal relationship. Thus, we conduct several additional analyses to gauge whether or not our findings are consistent with a causal story. First, following Tauras et al., and Farelly et al, we reestimate all models with a cumulative, instead of a current, measure of per capita program expenditures on tobacco control. This measure represents how much a given state has spent on tobacco control programs up to the present point in time, discounting previous period program expenditures by five percent. If the association between state spending and smoking behaviors is indeed causal, cumulative program expenditures should have stronger and more robust effects on smoking than current state tobacco program expenditures. We also test a specification with a one year lag of tobacco control program expenditures as the independent variable of interest, since program expenditures may take time to affect tobacco use behaviors.

Second, if tobacco control spending is effective in changing behaviors related to tobacco, one would expect that spending would have more impact on students who have had more exposure to tobacco control programming. Because we study college students, our sample includes individuals who have lived for a long period of time in their current state of residence as well as individuals who may have lived in their current state for only a short period of time, and who only live in that state for part of the year. The latter group therefore has less exposure to the tobacco control programming in their current state of residence compared to the former group. We can test whether greater exposure to tobacco control program efforts actually yields more benefits by re-estimating all models 
in a sub-sample of students who went to high school in the same state in which they attend college. If we observe more robust findings for this in-state sub-sample, this result would support the idea of a causal relationship.

Finally, because college students have long passed the typical age of smoking initiation, tobacco control efforts can reduce smoking prevalence in this age group mainly by helping them reduce or quit smoking (rather than by preventing initiation, which is relevant for younger teenagers). Thus, if tobacco control programming indeed causes changes in college students' smoking outcomes, we should initially see changes in reports of attempts to quit, followed eventually by decreased smoking prevalence and intensity. There is considerable evidence that terminating an addictive behavior such as smoking involves progressing through five stages: pre-contemplation, contemplation, preparation, action, and maintenance (32). Individuals in the pre-contemplation stage do not plan to change their smoking behaviors in the near future, while those in the contemplation stage are considering making changes but are not ready to do so yet. The preparation stage involves making plans to take action in the next month or so, and individuals in this stage may be reducing their frequency or intensity of smoking. During the action and maintenance stages, smokers actually quit cigarette use and work on maintaining abstinence. Typically, smokers spiral through these stages several times before quitting permanently (33). Thus, the probability of a successful quit is low for each attempt (particularly the first few) and as a result, it may take repeated and prolonged exposure to tobacco prevention programming to actually change the prevalence of smoking among young adults. For this reason, if our findings show more robust effects on attempts to quit smoking compared to smoking prevalence and intensity, this pattern would be consistent with a causal story. 


\subsection{Data}

The data used in this analysis are drawn from the 1993, 1997, 1999 and 2001 waves of the College Alcohol Study (CAS) conducted by the Harvard School of Public Health. In 1993, the CAS survey was administered to a random sample of students attending 140 randomly selected four-year colleges and universities across the United States (34). For each wave of the CAS, college administrators from each campus were asked to provide a random sample of undergraduates drawn from the total enrollment of full-time students. Depending on the enrollment size of each campus, every $n$th student was drawn from the school's full-time student registry. Over 250 students from each school were sent an anonymous survey to their registered school address. In 1997, 130 (35) in 1999, 128 (36) and in 2001, 120 of the original 140 colleges were resurveyed (37). The colleges surveyed in 2001 continue to reflect the national cross-section of students attending four-year colleges in terms of characteristics such as public versus private status, size, type of college (e.g., women's college), and urbanicity (37). A total of 17,592 students responded to the CAS survey mailings in 1993 followed by 15,685 responses in 1997, 14,907 replies in 1999 and 10,924 returned surveys in 2001 for a total of 59,098 respondents across all four survey years. In prior work, survey response rate was not found to be associated with substance use behaviors, specifically binge drinking rates (37).

Our main analysis sample includes a total of 58,640 respondents; of this group, 27,114 attend college in the same state in which they completed their high school education. The analysis sample excludes small numbers of observations with missing data on marital status $(n=276)$ and gender $(n=182)$. For respondents with missing information about their age, race, ethnicity, year in school, residence, sorority/fraternity membership or parental education, missing data were imputed with sample means. The 
models included a missing data indicator for each of these variables that was set equal to one if an imputed value was used, zero otherwise. For models of quit attempts, we limit the main sample to respondents from the 1997, 1999, and 2001 surveys, since questions about quitting smoking were not asked in the 1993 survey (below, we describe how we further limit the sample to respondents who are at risk of quitting smoking). Similarly, we only use data from 1999 and 2001 when analyzing the cigar outcome, since this question was not asked in prior years.

\subsection{Tobacco use outcome measures}

Although the CAS surveys were designed primarily to investigate drinking behaviors across U.S. college campuses, other risky behaviors, including tobacco use behaviors, also were examined. To measure the prevalence of smoking, we use a dummy indicator set equal to one if the respondent reports any use of cigarettes in the past 30 days and zero otherwise. To proxy intensity of smoking, we use a "continuous" measure of daily cigarette consumption that takes on the value of 0 (no cigarettes smoked per day), .5 (on average, less than one cigarette), 5 (less than half a pack), 10 (about half a pack), 15 (more than half a pack, but less than a pack), 20 (a pack) or 30 (more than a pack). Models of smoking intensity are limited to respondents who report any smoking in the past 30 days. Smokeless tobacco questions were asked in all years, but cigar use questions were only asked in the 1999 and 2001 surveys. Based on these data, we create two indicators of use - a dummy indicator for any use of smokeless tobacco in the past 30 days, and a dummy indicator for any use of cigars in the past 30 days. Data on the intensity of smokeless tobacco and cigar use are not available.

\section{Attempts to quit smoking}

In the 1997, 1999 and 2001 waves of the CAS surveys, all respondents were asked about their smoking cessation behavior. More specifically, the students were asked 
the following: "In the past 12 months, how many times have you tried to quit smoking and succeeded for at least 24 hours?” Possible responses included: Never, Once, Twice, 3 times, 4 times, 5 or more times. Based upon this question, we constructed two measures of smoking cessation. The first smoking cessation measure is a dichotomous indicator that is equal to one if the respondent has tried to quit smoking at least once for at least a period of 24 hours within the past 12 months and zero if the student reports no attempts to quit. The second measure of smoking cessation behavior reflects the frequency of cessation attempts. It is an ordered level measure which equals a value of: zero for no cessation attempts; 1 for one 24 hour attempt; 2 for two 24-hour attempts; 3 for three 24hour attempts, 4 for four 24 hour attempts and 5 for five or more 24-hour attempts. Because the number of quits measure is censored on the right hand side, in sensitivity analyses, we explored whether changing the value of "five or more attempts" to 6 instead of 5 affects our findings. Our results were not affected by this change; these findings are not shown in the paper (results available upon request from corresponding author).

We estimate the smoking cessation models using three alternative samples of respondents who may be at risk for quitting smoking. The broadest sample includes all respondents who reported any cigarette use in the past year. The advantage of estimating the smoking cessation models using this sample is that we will have captured all respondents who made an attempt to quit in the past year, including those who currently smoke but have made unsuccessful attempts to quit as well as successful quitters who report smoking in the past year but do not report any current smoking. The disadvantage of using this sample is that it includes many respondents who rarely smoke, or have smoked only a few times in the past year, and would not consider themselves to be smokers. In our sample, for example, among past year smokers, about 38 percent report no current daily smoking and an additional 20 percent report currently smoking less than 
one cigarette per day. Thus, the past year smoker sample may include a large number of respondents who were never at risk of quitting, since they don't smoke regularly, and therefore could not conceivably have been influenced by state tobacco control programs. ${ }^{4}$

Since quitting should only be a potential outcome for those who consider themselves to be smokers, in addition to using the past year smokers sample, we also estimate the smoking cessation models using two other, more narrowly defined groups of smokers - "at least occasional smokers" and "established smokers." These two groups are created based on the following survey question on daily smoking participation: "How many cigarettes a day do you smoke on average? (One pack equals 20 cigarettes)." Possible responses included none, less than one cigarette, less than a half a pack, about half a pack, more than half a pack but less than a pack, a pack, and more than a pack. Based on this question, the measure of at least occasional smoking participation is a dichotomous indicator where a student is considered to be "at least an occasional smoker" if he/she reported smoking less than one cigarette a day on average or more. The measure of established smoking is set to a value of one for students who smoke at least half a pack of cigarettes or more daily and zero otherwise. ${ }^{5}$ The advantage of estimating the cessation models using these two samples (at least occasional smoker, established smoker) is in both cases we have narrowed the analysis sample to those who smoke regularly and therefore potentially could be influenced to quit. The disadvantage of both these samples, however, is that they exclude those who have successfully quit in the past year.

\footnotetext{
${ }^{4}$ Since all CAS respondents were asked about attempts to quit smoking, another alternative would be to estimate the attempt to quit models using the entire sample. As a sensitivity check, we estimated the attempt to quit models using the entire sample. Findings were very similar to those based on the "past year smoker" sample and are not presented here (results available upon request from corresponding author).

${ }^{5}$ The definitions of at least occasional and established smoking behaviors derived from the CAS surveys in this analysis differ from those examined in previously published reports of tobacco use behaviors across US college campuses. These smoker definitions were created in an effort to capture the differences in smoking cessation behaviors between any current smokers (at least occasional smokers) and more addicted, daily smokers who report smoking at least half a pack of cigarettes or more per day (established smokers).
} 


\subsection{Tobacco control program expenditures}

We use three measures of state-level expenditures per capita on tobacco control programs: a current measure, a lagged measure, and a cumulative measure. We include the three measures separately, in alternative specifications. These variables were created by combining per capita state specific excise tax funding and other state appropriated funds earmarked for tobacco control programs with per capita non governmental statelevel program expenditures and per capita tobacco control program expenditures from ASSIST, IMPACT, SmokeLess States, and the National Tobacco Control Program. Information regarding the types of tobacco control interventions utilized by each program and funds spent on each individual intervention is not available. The first program expenditures measure is an annual, inflation-adjusted current fiscal year, per capita measure of tobacco control program expenditures within a given state. The second measure is a one-year lag of the first measure. The third measure is similar to the measure used by Hu et al. (22) in their evaluation of tobacco control programs in the State of California. This measure is a cumulative (with the earliest states having expenditures starting in 1986) inflation-adjusted measure of current and past tobacco control program expenditures made in a given state with previous periods discounted by 5 percent. The Consumer Price Index (CPI) is used to convert all expenditures measures into real 1990 dollars.

\subsection{Other state tobacco policies}

In order to capture the effects of other state-level policies related to tobacco, we also merged cigarette prices and information on clean indoor air laws into the CAS survey data. The cigarette price variable is a state-level average price per pack of 
cigarettes (in cents) merged with the CAS data according to the state location of the college campus. This state average cigarette price measure was drawn from the Tobacco Institute's annual Tax Burden on Tobacco and is based on the price of single cigarette packs, cartons and vending machine sales. It reflects the average price of a branded pack of twenty cigarettes inclusive of state level excise taxes. ${ }^{6}$ To account for changes in the relative price of cigarettes over time, cigarette prices were deflated by the national Consumer Price Index published by the Bureau of Labor Statistics (1990=100) (38) .

We also merged a state-level clean indoor air law index into the college survey data. Data on seven separate smoking restrictions were obtained from the The ImpacTeen State Level Tobacco Legislative Database and were used to construct the index which includes restrictions on smoking in private worksites, restaurants, shopping malls, cultural facilities, recreational facilities, health care facilities and public transit facilities. Each of these restrictions takes on a value of 0 through 5, depending on the strength of the regulation. This index was derived by summing the restriction ratings for each of the seven regulations and gives extra weight (double) to restrictions on smoking in places that are likely to be frequented by college students and specifically include restaurants, shopping malls, recreational facilities and cultural facilities.

\subsection{College characteristics}

In addition to interviewing students, each wave of the CAS surveys also included an administrator questionnaire that surveyed deans of students or other administrators at each of the participating campuses. The school administrator surveys include a series of

\footnotetext{
${ }^{6}$ Cigarette brand choice in the age group we study is dominated by premium brands. The average cigarette price measure we use in the paper therefore does not include the price of generic cigarette brands. We also tested various specifications using an average price measure which reflects generic brands as well as a local measure of cigarette prices drawn from the American Chamber of Commerce Researchers' Association were also tested. The findings presented are not sensitive to the measure of cigarette price included.
} 
questions pertaining to campus policies toward student substance abuse and other substance use-related aspects of the campus environment. Beginning in 1997, the CAS school administrator survey included an extensive series of questions pertaining to campus policies toward tobacco. In that year, information on the rules surrounding tobacco advertising on campus, the availability and sale of tobacco on campus, and the presence of smoking restrictions and the degree of their enforcement was obtained for 1993 and 1997 academic years. In 1999 and 2001, the CAS school administrator survey gathered comparable tobacco-related campus policy information for these respective years.

Drawing upon information from the CAS School Administrator surveys, a series of variables capturing each school's smoking policy were constructed. These include: smoking prohibited everywhere on campus, prohibited in public areas, prohibited in most areas and generally not prohibited. Although this analysis tested several combinations of these variables, only a dichotomous indicator that equals one if smoking is prohibited everywhere on campus and zero otherwise was selected for inclusion in the final specifications ${ }^{7}$. Finally, also by drawing on the CAS Administrators' questionnaire, information on the type of campus (all female, traditionally African-American, small private, large private, commuter campus, small public or large public) also was included in the analysis.

\footnotetext{
${ }^{7}$ Among the campus-level tobacco control policies tested, only the dichotomous indicator for 'smoking prohibited everywhere on campus' revealed statistical significance in these empirical models. The remaining campus-level policy measures (ie. prohibited in public areas, prohibited in most areas and generally not prohibited) consistently yielded insignificant implications for the outcome measures reviewed in this analysis.
} 


\subsection{Student characteristics}

The CAS student surveys collected a variety of demographic and socioeconomic data. In this analysis, this information is used to control for other factors thought likely to affect college student smoking behaviors. These include: the age and age squared of the respondent, gender (males, females - reference group), year in school (Freshman reference category, Sophomore, Junior, Senior, $5^{\text {th }}$ year and beyond), race (African American, Asian, White - reference category, Native American, other), ethnicity (Hispanic), marital status (never married - reference category, married, divorced, separated, widowed), area of residence (single sex dormitory, co-ed dormitory, fraternity or sorority, other university housing, co-op or university affiliated group house, offcampus house/apartment - reference category), sorority or fraternity membership, student income (separated into allowance per week and wages earned per week) and parental education (either mother or father attended college).

\subsection{Geographic effects}

We use three alternative methods of controlling for geographic variation in sentiments towards smoking, which may be correlated with tobacco control program expenditures, as well as with individual attitudes towards smoking and smoking behaviors. Our first approach is the inclusion of state fixed effects based on the state in which the student attends college. Our second approach is to include three dummy variables (Northeast, South, and Midwest with West as the reference category) for the region in which the student attends college. Our third approach is the inclusion of a dichotomous indicator for whether or not the respondent attends a college campus that is located in a major tobacco producing state. This indicator takes on a value of one if the respondent's college campus is located in the state of Kentucky, North Carolina, Georgia, South Carolina, Tennessee or Virginia and zero otherwise. 


\subsection{Descriptive Statistics}

Summary statistics of all the variables based on the full sample are provided in Table 1. About 36 percent of the sample reports smoking cigarettes in the past year and 26 percent report smoking in the past 30 days. "At least occasional smokers" and "established smokers" comprise 23 percent and 8 percent of the sample respectively. The past 30 day prevalence rates of smokeless tobacco use and cigar use are 3.9 percent and 7.5 percent. The prevalence rate of any tobacco use ${ }^{8}$ within the past 30 days is 28.9 percent. Additionally, 6.5 percent of students report using multiple tobacco products within the last 30 days.

Based on the entire sample, 10 percent of respondents report at least one attempt to quit in the past 12 months, and the average number of attempts in the past 12 months (including zeros) was .32. Note that these average quit rates are based on the entire sample, which includes a large proportion of students who have not smoked in the past year. A closer look at quit behaviors among those students who reported smoking within the past year reveals that 32 percent of past year smokers reveal at least one attempt to quit smoking during the past 12 months with an average number of .96 attempts (including zeros) within the past 12 months. The average real per capita spending on tobacco control programs was $\$ .71$, and the average of cumulative per capita spending on tobacco control programs was $\$ 3.42$.

\subsection{Results}

\section{1 $\quad$ Attempts to quit smoking}

In Table 2, we show results from probit models in which, "at least one attempt to

\footnotetext{
${ }^{8}$ Defined as: any cigarette or smokeless tobacco use in the 1993 and 1997 waves and any cigarette, smokeless tobacco, cigar or pipe tobacco use in the 1999 and 2001 waves.
} 
quit smoking in the past year" is the dependent variable. Each cell represents a different model. Table 2 only shows the marginal effect and elasticity based on the estimated probit coefficient on tobacco control program expenditures (full regression results are available upon request). In the top panel, we show estimation results based on the entire sample while in the bottom panel, we show estimation results based on a sub-sample of in-state college students. In both panels, we display findings for models estimated on three groups of smokers separately, past year smokers, at least occasional smokers, and established smokers. Note that each column represents an alternate approach to including geographic effects - no geographic indicators included (column A), region indicators included (column B), indicator for tobacco producing state included (column C), and state fixed effects included (column D).

The findings in Table 2 show that for students who currently smoke, higher state program expenditures on tobacco control are associated with statistically significant increases in the probability of attempting to quit smoking at least once in the past year. These effects are evident in both the "at least occasional" and "established smoker" samples, but not in the "past year" smoker sample. Three findings are notable. First, the effects of program expenditures are most pronounced for established smokers, particularly those who are in-state college students (Table 2). This is consistent with a causal relationship between program expenditures and smoking outcomes since in-state students have had more exposure to tobacco programming than out-of-state students. For this group, elasticities range from .02 to .03. Second, in the total sample lagged and cumulative expenditures have more consistently statistically significant effects on attempting to quit compared to current expenditures (Table 2). Again, this pattern is intuitively appealing since one would expect there to be a lag in the effects of tobacco programs, and more expenditures should yield more benefits. Finally, with a few 
exceptions, the findings are not sensitive to the way in which we account for geography.

Table 3 shows results from negative binomial models in which the dependent variable is the number of quit attempts in the past year (including zeros). The pattern of results is similar to the "any attempt to quit models" in Table 2. When we consider students who have smoked in the past year, state tobacco control program spending is not associated with the number of attempts to quit smoking. The estimated coefficients on state program expenditures are inconsistent in sign and statistical significance. In the "at least occasional" and "established" smoker samples, however, almost all of the associations between state spending and the number of quit attempts are positive in sign. As in Table 2, in Table 3 we find the strongest associations between tobacco control program spending and the number of quit attempts in the in-state, established smoker sample. In this sample, current, lagged, and cumulative expenditures are all positively associated with the number of quit attempts, with elasticities ranging from .02 to .03 . The interpretation of our findings is not sensitive to how we treat geographic effects. In sum, Tables 2 and 3 present consistent findings that tobacco control program expenditures are positively associated with college students' efforts to quit smoking, particularly among in-state students who are established smokers.

\section{3 $\underline{\text { Tobacco use }}$}

Table 4 shows findings for models of smoking participation (any smoking in the past 30 days) and the log of cigarettes per day among those who have smoked in the past 30 days. The results in Table 4 show that there are no consistent associations between state tobacco control program expenditures and smoking participation and intensity. Although many (but not all) of the estimated coefficients on the tobacco control spending measures are negative in sign, they are not statistically significant at the 0.05 level in any of the models. This is true regardless of which tobacco control program expenditures 
measure is used (current, lagged, or cumulative), and which smoking outcome (participation or intensity) is considered.

In Table 5, however, we see quite a different pattern when any use of smokeless tobacco in the past 30 days and any use of cigars in the past 30 days are considered as outcomes. Considering smokeless tobacco first, the results in Table 5 show that in every specification, tobacco control program expenditures are associated with a statistically significant reduction in the use of smokeless tobacco. This result persists regardless of sample (total sample versus in-state sample), type of expenditure measure (current, lagged, cumulative), and how geographic effects are treated. Elasticities range from .06 to .12 , with the largest effects being those of cumulative expenditures on smokeless tobacco use in the in-state sample. When cigar use is the dependent variable, the findings indicate that lagged and cumulative expenditures have robust, negative associations with cigar use in the past 30 days. In this case, we find the largest effects being those of lagged expenditures on cigar use in the total sample, where elasticities are about .05. Some statistical significance is lost when the sample is limited to in-state students, possibly because of small sample sizes (cigar use is not a highly prevalent outcome). Current state expenditures are not associated with past 30 day cigar use.

\subsection{Conclusions}

Young adults, a group with high rates of tobacco use and many potential years of life ahead of them, perhaps have the most to gain from effective state tobacco control programs. This is particularly true of tobacco control efforts that assist individuals in quitting or reducing smoking, such as telephone quit lines, educational interventions, and media campaigns. The findings from this study consistently indicate that higher state spending on tobacco control programs is associated with increases in college students' attempts to quit smoking. We also find that higher tobacco program expenditures are 
associated with lower rates of smokeless tobacco and cigar use among college students.

Overall, the results are strongest in the in-state student sample, which may suggest that more exposure to tobacco control programs yields more benefits. We caution, however, that this is just one explanation for this finding. The in-state student sample may have other, unmeasured characteristics that can explain their apparent responsiveness to tobacco control programs.

Our findings suggest that state tobacco control efforts have promise in changing tobacco use behaviors among young adults, but efforts may need to be strengthened and intensified, become more comprehensive (so as to simultaneously include multiple tobacco control interventions that address price, information and regulatory activity) as well as targeted at and designed for young adults, in order to reduce the prevalence of smoking in this age group. Support should also specifically be allocated towards activities that support or enhance smoking cessation within the population (i.e. quit lines, other forms of cessation counseling, subsidized or free pharmacotherapies). Program expenditures on tobacco control, however, have been declining recently, in some cases quite dramatically. In Massachusetts, for example, funding for the state's comprehensive tobacco control program fell from $\$ 48$ million in 2002 to $\$ 2.5$ million in 2004 . As of 2006, only four states (Maine, Colorado, Mississippi, and Delaware) were spending the minimum level recommended by the CDC for comprehensive state tobacco control programs, and 35 states and the District of Columbia were spending less than half of what the CDC recommends or nothing at all (39). This decline in and lack of adequate funding for comprehensive tobacco control programs is troubling, given that the increasing evidence based on national data that these programs may be effective. To inform policy, we recommend that future researchers continue to study the effectiveness of state tobacco 
control program expenditures in changing smoking behaviors and attitudes, as well as explore methods for disseminating this information to decision makers. 


\section{$\underline{\text { References }}$}

1. Johnston L, O'Malley P, Bachman J, Schulenberg J. Monitoring the Future national results on adolescent drug use: Overview of key findings, 2005. (NIH Publication No. [yet to be assigned]). Bethesda, MD: National Institute on Drug Abuse, 2006.

2. Harvard School of Public Health College Alcohol Study. Authors' tabulations. 2006.

3. Centers for Disease Control and Prevention. Cigarette smoking among adults United States, 1994. MMWR, 1996:588-590.

4. Centers for Disease Control and Prevention. Cigarette smoking among adults United States, 2004: MMWR, 2005:1121-1124.

5. Nelson D, Mowery P, Tonar S, Marcus S, Giovino G, Zhao L. Trends in Smokeless Tobacc Use Among Adults and Adolescents in the United States. American Journal of Public Health 2006;96:897-905.

6. U.S. Department of Health and Human Services. Healthy People 2010 Conference Edition (Online). http://www.health.gov/healthypeople/Document/default.htm 2000.

7. U.S. Department of Health and Human Services. Reducing the Health Consequences of Smoking: 25 Years of Progress: A Report of the Surgeon General. DHHS Publication No. (CDC) 89-8411. Public Health Service, Centers for Disease Control, Center for Chronic Disease Prevention and Health Promotion, Office on Smoking and Health., 1989.

8. U.S. Department of Health and Human Services. The Health Consequences of Using Smokeless Tobacco: A Report of the Surgeon General. Washington, D.C.: U.S. Department of Health and Human Services, Public Health Service, 1986.

9. U.S. Department of Health and Human Services. The Surgeon General's 1990 Report on the Health Benefits of Smoking Cessation. MMWR 1990;39:2-10.

10. U.S. Department of Health and Human Services. The Health Consequences of Smoking: A Report of the Surgeon General. Executive Summary, 2004.

11. Chaloupka F, Warner K. The Economics of Smoking. In: Culyer A, Newhouse J, eds. Handbook of Health Economics. Netherlands: Elsevier Science, 2000:15411612.

12. Ross H, Chaloupka F. The effect of public policies and prices on youth smoking. Southern Economic Journal 2004;70:796-815.

13. Czart C, Pacula R, Chaloupka F, Wechsler H. The Impact of Prices and Control Policies on Cigarette Smoking Among College Students. Contemporary Economic Policy 2001;19:135-149.

14. Tauras J. Can public policy deter smoking escalation among young adults? Journal of Policy Analysis and Management 2005;24:771-784.

15. Chaloupka F, Tauras J, Grossman M. Public Policy and Youth Smokeless Tobacco Use. Southern Economic Journal 1997;64:503-516. 
16. Ohsfeldt R, Boyle R, Capilouto E. Affects of Tobacco Excise Taxes on the Use of Smokeless Tobacco Products in the U.S. Health Economics 1997;6: 525 - 531.

17. Chaloupka F, Warner K. Section 2.4: Econometric Studies of the Demand for Other Tobacco Products. Economics of Smoking: U.S. Department of Health and Human Services (USHHS), Preventing Tobacco Use Among Young People: A Report to the Surgeon General, 1994, 1994.

18. Centers for Disease Control and Prevention. Best Practices for Comprehensive Tobacco Control Programs-August 1999. Atlanta, GA: U.S. Department of Health and Human Services, Centers for Disease Control and Prevention, National Center for Chronic Disease Prevention and Health Promotion, Office on Smoking and Health, 1999.

19. Farrelly M, Pechacek T, Chaloupka F. The Impact of Tobacco Control Program Expenditures on Aggregate Cigarette Sales:1981-2000. Journal of Health Economics 2003;22:843-859.

20. Ong M, Alamar B, Glantz S. Health and Economic Effects of Two Proposals to Increase the California State Cigarette Excise Tax. Center for Tobacco Control Research and Education, 2003.

21. Pierce J, Gilpin E, Emery S, White M, Rosbrook M, Berry C. Has the California Tobacco Control Program Reduced Smoking? Journal of the American Medical Association 1998;280:893-899.

22. Hu T-W, Sung H-Y, Keller T. Reducing Cigarette Consumption in California: Tobacco Taxes vs. an Antismoking Media Campaign. American Journal of Public Health 1995;85:1218-1222.

23. Florida Department of Health. Florida Youth Tobacco Survey Reports: 2000. Florida Youth Tobacco Survey Results: Florida Department of Health, Bureau of Epidemiology, 2000.

24. Center for Disease Control and Prevention (CDC). Cigarette Smoking Before and After Excise Tax Increase and an Antismoking Campaign - Massachusetts, 19901996. MMWR 1996;45:966-970.

25. Centers for Disease Control and Prevention (CDC). Decline in Cigarette Consumption Following Implementation of a Comprehensive Tobacco Prevention and Education Program - Oregon, 1996-1998. MMWR 1999;48:140-143.

26. Tauras J, Chaloupka F, Farrelly M, et al. State Tobacco Control Spending and Youth Smoking. American Journal of Public Health 2005;95: 338-344.

27. Tauras J, Chaloupka F. Impact of Tobacco Control Spending and Tobacco Control Policies on Adolescents' Atitudes and Beliefs about Cigarette Smoking. Evidence-Based Preventive Medicine 2004;1:111-120.

28. Lantz P. Smoking on the rise among young adults: implications for research and policy. Tobacco Control 2003;60.

29. Johnston, LD et al., Institute for Social Research, University of Michigan. Monitoring the Future National Survey Results on Drug Use, 1975-2002. Volume I Secondary School Students, (2003), National Institute on Drug Abuse, NIH 
publication No. 03-5375

http://monitoringthefuture.org/pubs/mongraphs/vol1_2002.pdf

30. Ling P, Glantz S. Tobacco Industry Research on Smoking Cessation. Recapturing Young Adults and Other Recent Quitters. Journal of General Internal Medicine 2004;19:419-482.

31. Long J. Regression Models for Categorical and Limited Dependent Variables. Thousand Oaks, CA: Sage Publications, 1997.

32. Prochaska J, DiClemente C, Norcross J. In Search of How People Change. American Psychologist 1992:1002-1114.

33. Schachter S. Recidivism and Self-Cure of Smoking and Obesity. American Psychologist 1982;37:436-444.

34. Wechsler H, Davenport A, Dowdall G, Moeykens B, Castillo S. Health and Behavioral Consequences of Binge Drinking in College: A National Survey of Students at 140 Campuses. Journal of the American Medical Association 1994;272:1672-1677.

35. Wechsler H, Dowdall G, Maenner G, Gledhill-Hoyt J, Lee H. Changes in Binge Drinking and Related Problems Among American College Students Between 1993 and 1997. Journal of American College Health 1998;47:57-68.

36. Wechsler H, Lee J, Kuo M, Lee H. College Binge Drinking in the 1990s: A Continuing Problem - Results of the Harvard School of Public Health 1999 College Alcohol Study. Journal of American College Health 2000;48:199-210.

37. Wechsler H, Lee J, Kuo M, Seibring M, Nelson T, Lee H. Trends in College Binge Drinking During a Period of Increased Prevention Efforts: Findings From 4 Harvard School of Public Health College Alcohol Study Surveys: 1993-2001. Journal of American College Health 2002;50:203-217.

38. Bureau of Labor Statistics. Inflation \& Consumer Spending.

39. National Center for Tobacco-Free Kids. State Tobacco Settlement. Washington, D.C., 2006. 
Descriptive Statistics - CAS 1993, 1997, 1999 and 2001

\begin{tabular}{|c|c|c|}
\hline \multirow{2}{*}{ Variable } & \multicolumn{2}{|c|}{ Full Sample } \\
\hline & Mean & Std.Dev. \\
\hline \multicolumn{3}{|l|}{ Tobacco use } \\
\hline Past Year Cigarette Smoking & 0.36 & 0.48 \\
\hline Past 30-day Cigarette Smoking & 0.26 & 0.44 \\
\hline At Least Occasional Smoker & 0.23 & 0.42 \\
\hline Established Smoker & 0.08 & 0.28 \\
\hline Past 30-day smokeless tobacco use & 0.04 & 0.19 \\
\hline Past 30-day cigar use & 0.08 & 0.26 \\
\hline Any Tobacco Use within Past 30 days & 0.29 & 0.45 \\
\hline Multiple Tobacco Product Use within the Past 30 days & 0.07 & 0.25 \\
\hline \multicolumn{3}{|l|}{ Cessation Behavior } \\
\hline At least one attempt to quit within past 12 months (Full Sample) & 0.10 & 0.47 \\
\hline Number of quits within past 12 months (Full Sample) & 0.32 & 1.68 \\
\hline At least one attempt to quit within past 12 months (Past Year Smokers) & 0.32 & 0.30 \\
\hline Number of quits within past 12 months (Past Year Smokers) & 0.96 & 1.08 \\
\hline \multicolumn{3}{|l|}{ Tobacco Control Expenditures } \\
\hline Real per capita current fiscal year funding (in year 1990 dollars) & 0.71 & 1.24 \\
\hline Lagged real per capita current fiscal year funding (in year 1990 dollars) & 0.65 & 1.51 \\
\hline Real per capita cummulative funding (in year 1990 dollars) & 3.42 & 7.41 \\
\hline \multicolumn{3}{|l|}{ Cigarette Price Variable } \\
\hline Cigarettes (price per pack, in year 1990 dollars) & 152.21 & 30.48 \\
\hline \multicolumn{3}{|l|}{ Campus Smoking Policy Measure } \\
\hline Smoking Prohibited Everywhere on Campus & 0.12 & 0.32 \\
\hline Missing Smoking Prohibited Everywhere on Campus & 0.07 & 0.25 \\
\hline \multicolumn{3}{|l|}{ State Smoking Policy Measures } \\
\hline Smoke-Free Air Law Index & 10.21 & 6.60 \\
\hline \multicolumn{3}{|l|}{ Individual Student Characteristics } \\
\hline Male & 0.40 & 0.49 \\
\hline Age & 20.94 & 2.19 \\
\hline Age Missing & 0.00 & 0.02 \\
\hline \multicolumn{3}{|l|}{ Race } \\
\hline White & 0.77 & 0.42 \\
\hline African American & 0.07 & 0.25 \\
\hline Asian & 0.07 & 0.26 \\
\hline Native American & 0.01 & 0.08 \\
\hline Other Race & 0.07 & 0.26 \\
\hline Race Missing & 0.01 & 0.11 \\
\hline \multicolumn{3}{|l|}{ Ethnicity } \\
\hline Hispanic & 0.07 & 0.26 \\
\hline Ethnicity Missing & 0.00 & 0.06 \\
\hline \multicolumn{3}{|l|}{ Year of School } \\
\hline Freshman & 0.22 & 0.41 \\
\hline Sophomore & 0.21 & 0.41 \\
\hline Junior & 0.24 & 0.43 \\
\hline Senior & 0.23 & 0.42 \\
\hline 5th Year or Beyond & 0.08 & 0.27 \\
\hline Year in School Missing & 0.00 & 0.04 \\
\hline
\end{tabular}


Table one (continued)

\begin{tabular}{|c|c|c|}
\hline \multirow{2}{*}{ Variable } & \multicolumn{2}{|c|}{ Full Sample } \\
\hline & Mean & "Std.Dev. \\
\hline \multicolumn{3}{|l|}{ Marital Status } \\
\hline Single/Never Married & 0.90 & 0.31 \\
\hline Married & 0.08 & 0.27 \\
\hline Divorced & 0.02 & 0.14 \\
\hline Separated & 0.00 & 0.06 \\
\hline Widowed & 0.00 & 0.03 \\
\hline \multicolumn{3}{|l|}{ Living Arrangement } \\
\hline Live off-campus & 0.56 & 0.50 \\
\hline Unisex Dorm & 0.13 & 0.33 \\
\hline Co-Ed Dorm & 0.22 & 0.42 \\
\hline Other University Housing & 0.03 & 0.17 \\
\hline Live in Fraternity/Sorority & 0.03 & 0.17 \\
\hline Other Housing & 0.03 & 0.16 \\
\hline Living Arrangement Missing & 0.01 & 0.07 \\
\hline \multicolumn{3}{|l|}{ Sorority/Fraternity Membership } \\
\hline Member of a sorority or fraternity & 0.14 & 0.35 \\
\hline Sorority/Fraternity Member Information Missing & 0.00 & 0.06 \\
\hline \multicolumn{3}{|l|}{ Parent Education (At least one attended college) } \\
\hline At least parent attended college & 0.79 & 0.41 \\
\hline Parental College Education Information Missing & 0.03 & 0.16 \\
\hline \multicolumn{3}{|l|}{ 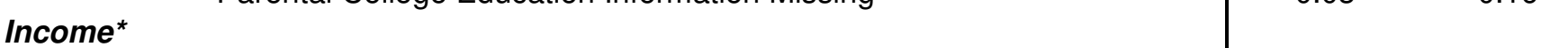 } \\
\hline Real Wage Income (Year 1990 dollars/week) & 34.80 & 34.76 \\
\hline Missing Real Wage Income & 0.01 & 0.11 \\
\hline Real Allowance Income (Year 1990 dollars/week) & 19.05 & 28.18 \\
\hline Missing Real Allowance Income & 0.02 & 0.15 \\
\hline \multicolumn{3}{|l|}{ University Characteristics } \\
\hline Woman's College & 0.04 & 0.21 \\
\hline African American College & 0.02 & 0.14 \\
\hline Commuter College & 0.15 & 0.36 \\
\hline Small Private College & 0.11 & 0.32 \\
\hline Large Private College & 0.14 & 0.35 \\
\hline Small Public College & 0.15 & 0.36 \\
\hline Large Public College & 0.37 & 0.48 \\
\hline \multicolumn{3}{|l|}{ Campus Location } \\
\hline Tobacco Producing State & 0.11 & 0.32 \\
\hline Northeast & 0.23 & 0.42 \\
\hline South & 0.29 & 0.45 \\
\hline West & 0.18 & 0.38 \\
\hline Midwest & 0.30 & 0.46 \\
\hline \multicolumn{3}{|l|}{ Survey Wave Dummy Variables } \\
\hline Year 1993 Dummy & 0.30 & 0.46 \\
\hline Year 1997 Dummy & 0.27 & 0.44 \\
\hline Year 1999 Dummy & 0.25 & 0.43 \\
\hline Year 2001 Dummy & 0.18 & 0.39 \\
\hline Sample Size & \multicolumn{2}{|c|}{58640} \\
\hline
\end{tabular}




\begin{tabular}{|c|c|c|c|c|c|c|c|c|c|c|c|c|}
\hline \multicolumn{13}{|c|}{$\begin{array}{r}\text { Table 2: At least one attempt to quit s } \\
\text { Probit Model }\end{array}$} \\
\hline \multicolumn{13}{|c|}{$\begin{array}{c}\text { Marginal Effect } \\
\text { (T-statistic) } \\
\text { [Elasticity] } \\
\end{array}$} \\
\hline & \multicolumn{4}{|c|}{ I. Smoked in past year } & \multicolumn{4}{|c|}{ II. At Least Occasional Smokers } & \multicolumn{4}{|c|}{ III. Established Smokers } \\
\hline & A & B & C & $\mathrm{D}$ & A & $\mathrm{B}$ & C & $\mathrm{D}$ & A & $\mathrm{B}$ & C & $\mathrm{D}$ \\
\hline \multicolumn{13}{|l|}{ Total Sample } \\
\hline $\begin{array}{l}\text { Current state } \\
\text { expenditures on } \\
\text { tobacco control }\end{array}$ & $\begin{array}{c}0.0005 \\
(0.95) \\
{[0.0009]}\end{array}$ & $\begin{array}{c}0.0014 \\
(0.33) \\
{[0.0026]}\end{array}$ & $\begin{array}{c}0.0005 \\
(0.06) \\
{[0.0009]}\end{array}$ & $\begin{array}{c}0.0005 \\
0.06 \\
{[0.0009]}\end{array}$ & $\begin{array}{c}0.0005 \\
(0.1) \\
{[0.0007]}\end{array}$ & $\begin{array}{c}0.0008 \\
(0.19) \\
{[0.0011]}\end{array}$ & $\begin{array}{c}0.0008 \\
(0.16) \\
{[0.0012]}\end{array}$ & $\begin{array}{c}0.0005 \\
(0.10) \\
{[0.0007]}\end{array}$ & $\begin{array}{c}0.0097 \\
(1.38) \\
{[0.0130]}\end{array}$ & $\begin{array}{c}0.0082 \\
(1.28) \\
{[0.0111]}\end{array}$ & $\begin{array}{c}0.0097 \\
(1.37) \\
{[0.0130]}\end{array}$ & $\begin{array}{c}0.0097 \\
(1.38) \\
{[0.0130]}\end{array}$ \\
\hline $\begin{array}{l}\text { Lagged state } \\
\text { expenditures on } \\
\text { tobacco control }\end{array}$ & $\begin{array}{c}0.0041 \\
(0.85) \\
{[0.0067]}\end{array}$ & $\begin{array}{c}0.0026 \\
(0.86) \\
{[0.0043]}\end{array}$ & $\begin{array}{c}0.0041 \\
(0.84) \\
{[0.0068]}\end{array}$ & $\begin{array}{c}0.0041 \\
(0.85) \\
{[0.0067]}\end{array}$ & $\begin{array}{c}0.0061 \\
(2.13) \\
{[0.0077]}\end{array}$ & $\begin{array}{c}0.0051 \\
(1.90) \\
{[0.0065]}\end{array}$ & $\begin{array}{c}0.0066 \\
(2.26) \\
{[0.0084]}\end{array}$ & $\begin{array}{c}0.0061 \\
(2.13) \\
{[0.0077]}\end{array}$ & $\begin{array}{c}0.0148 \\
(3.79) \\
{[0.0180]}\end{array}$ & $\begin{array}{c}0.0138 \\
(4.05) \\
{[0.0167]}\end{array}$ & $\begin{array}{c}0.0148 \\
(3.75) \\
{[0.0180]}\end{array}$ & $\begin{array}{c}0.0148 \\
(3.79) \\
{[0.0180]}\end{array}$ \\
\hline $\begin{array}{c}\text { Cumulative } \\
\text { state } \\
\text { expenditures on } \\
\text { tobacco control }\end{array}$ & $\begin{array}{c}0.0003 \\
(0.25) \\
{[0.0029]}\end{array}$ & $\begin{array}{c}0.0005 \\
(0.94) \\
{[0.0047]}\end{array}$ & $\begin{array}{c}0.0003 \\
(0.25) \\
{[0.0029]}\end{array}$ & $\begin{array}{c}0.0003 \\
(0.25) \\
{[0.0029]}\end{array}$ & $\begin{array}{c}0.001 \\
(1.36) \\
{[0.0068]}\end{array}$ & $\begin{array}{c}0.0011 \\
(2.49) \\
{[0.0073]}\end{array}$ & $\begin{array}{c}0.0011 \\
(1.46) \\
{[0.0076]}\end{array}$ & $\begin{array}{c}0.001 \\
(1.36) \\
{[0.0068]}\end{array}$ & $\begin{array}{c}0.0031 \\
(4.07) \\
{[0.0197]}\end{array}$ & $\begin{array}{c}0.0029 \\
(4.79) \\
{[0.0185]}\end{array}$ & $\begin{array}{c}0.0031 \\
(4.00) \\
{[0.0197]}\end{array}$ & $\begin{array}{c}0.0031 \\
(4.07) \\
{[0.0197]}\end{array}$ \\
\hline \multicolumn{13}{|l|}{$\begin{array}{l}\text { In-state } \\
\text { Sample }\end{array}$} \\
\hline $\begin{array}{l}\text { Current state } \\
\text { expenditures on } \\
\text { tobacco control }\end{array}$ & $\begin{array}{c}-0.002 \\
(-0.16) \\
{[-0.0032]}\end{array}$ & $\begin{array}{c}0.0008 \\
(0.20) \\
{[0.0009]}\end{array}$ & $\begin{array}{c}-0.001 \\
(-0.14) \\
{[-0.0031]}\end{array}$ & $\begin{array}{c}-0.002 \\
(-0.16) \\
{[-0.0032]}\end{array}$ & $\begin{array}{c}-0.002 \\
(-0.37) \\
{[-0.0029]}\end{array}$ & $\begin{array}{c}-0.001 \\
(-0.25) \\
{[-0.0014]}\end{array}$ & $\begin{array}{c}-0.002 \\
(-0.29) \\
{[-0.0024]}\end{array}$ & $\begin{array}{c}-0.002 \\
(-0.37) \\
{[-0.0029]}\end{array}$ & $\begin{array}{c}0.0228 \\
(3.00) \\
{[0.0266]}\end{array}$ & $\begin{array}{c}0.0205 \\
(2.84) \\
{[0.0239]}\end{array}$ & $\begin{array}{c}0.0228 \\
(2.99) \\
{[0.0266]}\end{array}$ & $\begin{array}{c}0.0228 \\
(3.00) \\
{[0.0266]}\end{array}$ \\
\hline $\begin{array}{l}\text { Lagged state } \\
\text { expenditures on } \\
\text { tobacco control }\end{array}$ & $\begin{array}{c}0.0061 \\
(1.10) \\
{[0.0083]}\end{array}$ & $\begin{array}{c}0.0046 \\
(1.40) \\
{[0.0061]}\end{array}$ & $\begin{array}{c}0.0064 \\
(1.12) \\
{[0.0085]}\end{array}$ & $\begin{array}{c}0.0061 \\
(1.10) \\
{[0.0083]}\end{array}$ & $\begin{array}{c}0.0035 \\
(1.89) \\
{[0.0073]}\end{array}$ & $\begin{array}{c}0.0056 \\
(1.48) \\
{[0.0062]}\end{array}$ & $\begin{array}{c}0.0073 \\
(2.03) \\
{[0.0081]}\end{array}$ & $\begin{array}{c}0.0066 \\
(1.89) \\
{[0.0073]}\end{array}$ & $\begin{array}{c}0.0236 \\
(4.51) \\
{[0.0249]}\end{array}$ & $\begin{array}{c}0.0219 \\
(4.59) \\
{[0.0231]}\end{array}$ & $\begin{array}{c}0.0236 \\
(4.51) \\
{[0.0250]}\end{array}$ & $\begin{array}{c}0.0236 \\
(4.51) \\
{[0.0249]}\end{array}$ \\
\hline $\begin{array}{c}\text { Cumulative } \\
\text { state } \\
\text { expenditures on } \\
\text { tobacco control }\end{array}$ & $\begin{array}{c}0.0004 \\
(0.26) \\
{[0.0030]}\end{array}$ & $\begin{array}{c}0.0009 \\
(1.66) \\
{[0.0066]}\end{array}$ & $\begin{array}{c}0.0005 \\
(0.28) \\
{[0.0032]}\end{array}$ & $\begin{array}{c}0.0004 \\
(0.26) \\
{[0.0030]}\end{array}$ & $\begin{array}{c}0.0007 \\
(0.68) \\
{[0.0042]}\end{array}$ & $\begin{array}{c}0.0009 \\
(1.57) \\
{[0.0056]}\end{array}$ & $\begin{array}{c}0.0008 \\
(0.79) \\
{[0.0051]}\end{array}$ & $\begin{array}{c}0.0007 \\
(0.68) \\
{[0.0042]}\end{array}$ & $\begin{array}{c}0.0048 \\
(5.07) \\
{[0.0260]}\end{array}$ & $\begin{array}{c}0.0044 \\
(5.09) \\
{[0.0241]}\end{array}$ & $\begin{array}{c}0.0048 \\
(5.02) \\
{[0.0261]}\end{array}$ & $\begin{array}{c}0.0048 \\
(5.07) \\
{[0.0260]}\end{array}$ \\
\hline
\end{tabular}

Model $A=S t a n d a r d /$ No location specific control variables; Model $B=$ Region Indicators; Model $C=I n d i c a t o r$ of tobacco producing state; Model $D=S t a t e$ Fixed Effects 
Table 3: Number of attempts to quit smoking in past 12 months

\begin{tabular}{|c|c|c|c|c|c|c|c|c|c|c|c|c|}
\hline \multicolumn{13}{|c|}{$\begin{array}{r}\text { Table 3: } \\
\text { Number of attempts to quit smoki } \\
\text { Negative Binomial Model }\end{array}$} \\
\hline \multicolumn{13}{|c|}{$\begin{array}{l}\text { Coefficient } \\
\text { (T-statistic) } \\
\text { [Elasticity] }\end{array}$} \\
\hline & \multicolumn{4}{|c|}{ I. Smoked in past year } & \multicolumn{4}{|c|}{ II. At Least Occasional Smokers } & \multicolumn{4}{|c|}{ III. Established Smokers } \\
\hline & $A$ & $\mathrm{~B}$ & $\mathrm{C}$ & $\mathrm{D}$ & A & $\mathrm{B}$ & C & $\mathrm{D}$ & A & $B$ & $\mathrm{C}$ & $\mathrm{D}$ \\
\hline \multicolumn{13}{|l|}{ Total Sample } \\
\hline $\begin{array}{l}\text { Current state } \\
\text { expenditures on } \\
\text { tobacco control }\end{array}$ & $\begin{array}{c}-0.0005 \\
(-0.11) \\
{[-0.0013]}\end{array}$ & \begin{tabular}{|c|}
0.0003 \\
$(0.03)$ \\
{$[0.0003]$} \\
\end{tabular} & $\begin{array}{c}-0.0014 \\
(-0.10) \\
{[-0.0012]}\end{array}$ & \begin{tabular}{|c|}
-0.0015 \\
$(-0.11)$ \\
{$[-0.0013]$} \\
\end{tabular} & $\begin{array}{c}0.0001 \\
(0.01) \\
{[0.0001]}\end{array}$ & $\begin{array}{c}0.0003 \\
(0.03) \\
{[0.0002]}\end{array}$ & $\begin{array}{c}0.0009 \\
(0.13) \\
{[0.0008]}\end{array}$ & $\begin{array}{c}0.0001 \\
(0.01) \\
{[0.0001]} \\
\end{array}$ & \begin{tabular}{|c|}
0.0176 \\
$(1.01)$ \\
{$[0.0143]$} \\
\end{tabular} & \begin{tabular}{|c|}
0.0133 \\
$(0.95)$ \\
{$[0.0108]$} \\
\end{tabular} & \begin{tabular}{|c|}
0.0173 \\
$(0.99)$ \\
{$[0.0141]$} \\
\end{tabular} & $\begin{array}{r}0.0176 \\
(1.01) \\
{[0.0143} \\
\end{array}$ \\
\hline $\begin{array}{l}\text { Lagged state } \\
\text { expenditures on } \\
\text { tobacco control }\end{array}$ & $\begin{array}{c}0.0014 \\
(0.17) \\
{[0.0011]}\end{array}$ & $\begin{array}{c}-0.0009 \\
(-0.13) \\
{[-0.0007]} \\
\end{array}$ & $\begin{array}{c}0.0016 \\
(0.19) \\
{[0.0012]}\end{array}$ & \begin{tabular}{|c|}
0.0014 \\
$(0.17)$ \\
{$[0.0011]$} \\
\end{tabular} & $\begin{array}{c}0.0057 \\
(1.07) \\
{[0.0044]} \\
\end{array}$ & $\begin{array}{c}0.0055 \\
(0.99) \\
{[0.0042]}\end{array}$ & $\begin{array}{c}0.0070 \\
(1.47) \\
{[0.0054]}\end{array}$ & $\begin{array}{c}0.0057 \\
(1.07) \\
{[0.0044]} \\
\end{array}$ & \begin{tabular}{|c|}
0.0130 \\
$(1.16)$ \\
{$[0.0096]$} \\
\end{tabular} & \begin{tabular}{|c|}
0.0122 \\
$(1.41)$ \\
{$[0.0089]$} \\
\end{tabular} & \begin{tabular}{|c|}
0.0126 \\
$(1.11)$ \\
{$[0.0093]$} \\
\end{tabular} & $\begin{array}{c}0.0130 \\
(1.16) \\
{[0.0096} \\
\end{array}$ \\
\hline $\begin{array}{l}\text { Cumulative state } \\
\text { expenditures on } \\
\text { tobacco control }\end{array}$ & $\begin{array}{c}0.0003 \\
(0.12) \\
{[0.0010]} \\
\end{array}$ & \begin{tabular}{|c|}
0.0006 \\
$(0.52)$ \\
{$[0.0024]$} \\
\end{tabular} & $\begin{array}{c}0.0003 \\
(0.14) \\
{[0.0012]}\end{array}$ & \begin{tabular}{|c|}
0.0003 \\
$(0.12)$ \\
{$[0.0010]$} \\
\end{tabular} & $\begin{array}{c}0.0017 \\
(1.73) \\
{[0.0067]} \\
\end{array}$ & $\begin{array}{c}0.0017 \\
(1.81) \\
{[0.0067]}\end{array}$ & $\begin{array}{c}0.0019 \\
(2.33) \\
{[0.0079]}\end{array}$ & $\begin{array}{c}0.0017 \\
(1.73) \\
{[0.0067]} \\
\end{array}$ & \begin{tabular}{|c|}
0.0036 \\
$(1.48)$ \\
{$[0.0135]$} \\
\end{tabular} & \begin{tabular}{|c|}
0.0029 \\
$(1.74)$ \\
{$[0.0110]$} \\
\end{tabular} & \begin{tabular}{|c|}
0.0035 \\
$(1.44)$ \\
{$[0.0132]$} \\
\end{tabular} & $\begin{array}{r}0.0036 \\
(1.48) \\
{[0.0135} \\
\end{array}$ \\
\hline \multicolumn{13}{|l|}{ In-state Sample } \\
\hline $\begin{array}{l}\text { Current state } \\
\text { expenditures on } \\
\text { tobacco control }\end{array}$ & $\begin{array}{c}-0.0020 \\
(-0.13) \\
{[-0.0015]}\end{array}$ & \begin{tabular}{|c|}
0.0040 \\
$(0.43)$ \\
{$[0.0029]$} \\
\end{tabular} & $\begin{array}{c}-0.0015 \\
(-0.09) \\
{[-0.0011]}\end{array}$ & $\begin{array}{c}-0.0020 \\
(-0.13) \\
{[-0.0015]} \\
\end{array}$ & $\begin{array}{c}-0.0009 \\
(-0.09) \\
{[-0.0007]}\end{array}$ & $\begin{array}{c}0.0005 \\
(0.05) \\
{[0.0004]}\end{array}$ & $\begin{array}{c}0.0007 \\
(0.07) \\
{[0.0005]}\end{array}$ & $\begin{array}{c}-0.0009 \\
(-0.09) \\
{[-0.0007]}\end{array}$ & \begin{tabular}{|c|}
0.0477 \\
$(2.12)$ \\
{$[0.0332]$} \\
\end{tabular} & \begin{tabular}{|c|}
0.0406 \\
$(2.5)$ \\
{$[0.0283]$} \\
\end{tabular} & \begin{tabular}{|c|}
0.0481 \\
$(2.16)$ \\
0.0335 \\
\end{tabular} & $\begin{array}{l}0.0477 \\
(2.12) \\
0.0332 \\
\end{array}$ \\
\hline $\begin{array}{l}\text { Lagged state } \\
\text { expenditures on } \\
\text { tobacco control }\end{array}$ & $\begin{array}{c}0.0070 \\
(0.71) \\
{[0.0045]}\end{array}$ & $\begin{array}{c}0.0058 \\
(0.63) \\
{[0.0037]} \\
\end{array}$ & $\begin{array}{c}0.0079 \\
(0.77) \\
{[0.0051]}\end{array}$ & \begin{tabular}{|c|}
0.0070 \\
$(0.71)$ \\
{$[0.0045]$} \\
\end{tabular} & $\begin{array}{c}0.0062 \\
(0.93) \\
{[0.0041]}\end{array}$ & $\begin{array}{c}0.0071 \\
(1.04) \\
{[0.0047]}\end{array}$ & $\begin{array}{c}0.0085 \\
(1.42) \\
{[0.0057]}\end{array}$ & $\begin{array}{c}0.0062 \\
(0.93) \\
{[0.0041]}\end{array}$ & \begin{tabular}{|c|}
0.0346 \\
$(2.59)$ \\
{$[0.0219]$} \\
\end{tabular} & $\begin{array}{c}0.0326 \\
(3.55) \\
{[0.0206]} \\
\end{array}$ & \begin{tabular}{|c|}
0.0353 \\
$(2.69)$ \\
{$[0.0223]$} \\
\end{tabular} & $\begin{array}{r}0.0346 \\
(2.59) \\
{[0.0219} \\
\end{array}$ \\
\hline $\begin{array}{l}\text { Cumulative state } \\
\text { expenditures on } \\
\text { tobacco control }\end{array}$ & $\begin{array}{c}0.0012 \\
(043) \\
{[0.0041]}\end{array}$ & $\begin{array}{c}0.0022 \\
(1.48) \\
{[0.0076]}\end{array}$ & $\begin{array}{c}0.0013 \\
(0.48) \\
{[0.0047]}\end{array}$ & $\begin{array}{c}0.0012 \\
(0.43) \\
{[0.0041]}\end{array}$ & $\begin{array}{c}0.0017 \\
(1.36) \\
{[0.0063]}\end{array}$ & $\begin{array}{c}0.0020 \\
(1.73) \\
{[0.0074]}\end{array}$ & $\begin{array}{c}0.0022 \\
(1.89) \\
{[0.0081]}\end{array}$ & $\begin{array}{c}0.0017 \\
(1.36) \\
{[0.0063]}\end{array}$ & $\begin{array}{c}0.0085 \\
(3.06) \\
{[0.0279]}\end{array}$ & $\begin{array}{c}0.0074 \\
(4.25) \\
{[0.0242]}\end{array}$ & $\begin{array}{c}0.0087 \\
(3.17) \\
{[0.0284]}\end{array}$ & $\begin{array}{r}0.0085 \\
(3.06) \\
{[0.0279]}\end{array}$ \\
\hline
\end{tabular}

Model $A=S t a n d a r d /$ No location specific control variables; Model $B=$ Region Indicators; Model $C=$ Indicator of tobacco producing state; Model $D=S t a t e$ Fixed Effects 
Table 4: Prevalence and Intensity of Cigarette Use in Past 30 Days

\begin{tabular}{|c|c|c|c|c|c|c|c|c|}
\hline & \multicolumn{4}{|c|}{$\begin{array}{c}\text { Probit Model } \\
\text { Marginal Effect } \\
\text { (T-statistic) } \\
\text { [Elasticity] }\end{array}$} & \multicolumn{4}{|c|}{$\begin{array}{l}\text { OLS model } \\
\text { Coefficient } \\
\text { (T-statistic) } \\
\text { [Elasticity] }\end{array}$} \\
\hline & \multicolumn{4}{|c|}{ I. Smoked in past 30 days } & \multicolumn{4}{|c|}{ II. Number of cigarettes per day } \\
\hline & $A$ & $B$ & C & $\mathrm{D}$ & $A$ & $B$ & $\mathrm{C}$ & $\mathrm{D}$ \\
\hline Total Sample & & & & & & & & \\
\hline $\begin{array}{c}\text { Current state expenditures } \\
\text { on tobacco control }\end{array}$ & $\begin{array}{c}-0.0038 \\
(-0.64) \\
{[-0.0108]}\end{array}$ & $\begin{array}{c}-0.0007 \\
(-0.23) \\
{[-0.0020]}\end{array}$ & $\begin{array}{c}-0.0039 \\
(-0.65) \\
{[-0.0110]}\end{array}$ & $\begin{array}{c}-0.0038 \\
(-0.64) \\
{[-0.0108]}\end{array}$ & $\begin{array}{c}-0.0019 \\
(-0.06) \\
{[-0.0010]}\end{array}$ & $\begin{array}{c}0.0090 \\
(0.65) \\
{[0.0045]}\end{array}$ & $\begin{array}{c}-0.0011 \\
(-0.03) \\
{[-0.0006]}\end{array}$ & $\begin{array}{c}-0.0019 \\
(-0.06) \\
{[-0.0010]}\end{array}$ \\
\hline $\begin{array}{l}\text { Lagged state expenditures } \\
\text { on tobacco control }\end{array}$ & $\begin{array}{c}-0.0033 \\
(-0.72) \\
{[-0.0085]}\end{array}$ & $\begin{array}{c}-0.0033 \\
(-1.37) \\
{[-0.0084]}\end{array}$ & $\begin{array}{c}-0.0034 \\
(-0.74) \\
{[-0.0087]}\end{array}$ & $\begin{array}{c}-0.0033 \\
(-0.72) \\
{[-0.0085]}\end{array}$ & $\begin{array}{c}0.0095 \\
(0.35) \\
{[0.0043]}\end{array}$ & $\begin{array}{c}0.0073 \\
(0.51) \\
{[0.0033]}\end{array}$ & $\begin{array}{c}0.0107 \\
(0.38) \\
{[0.0048]}\end{array}$ & $\begin{array}{c}0.0095 \\
(0.35) \\
{[0.0043]}\end{array}$ \\
\hline $\begin{array}{c}\text { Cumulative state } \\
\text { expenditures on tobacco } \\
\text { control } \\
\end{array}$ & $\begin{array}{c}-0.0010 \\
(-0.91) \\
{[-0.0135]} \\
\end{array}$ & $\begin{array}{c}-0.0006 \\
(-1.15) \\
{[-0.0075]} \\
\end{array}$ & $\begin{array}{c}-0.0010 \\
(-0.94) \\
{[-0.0138]} \\
\end{array}$ & $\begin{array}{c}-0.0010 \\
(-0.91) \\
{[-0.0135]} \\
\end{array}$ & $\begin{array}{c}0.0000 \\
(0.01) \\
{[0.0001]} \\
\end{array}$ & $\begin{array}{c}0.0016 \\
(0.51) \\
{[0.0038]} \\
\end{array}$ & $\begin{array}{c}0.0003 \\
(0.04) \\
{[0.0007]} \\
\end{array}$ & $\begin{array}{c}0.0000 \\
(0.01) \\
{[0.0001]}\end{array}$ \\
\hline \multicolumn{9}{|l|}{ In-state Sample } \\
\hline $\begin{array}{l}\text { Current state expenditures } \\
\text { on tobacco control }\end{array}$ & $\begin{array}{c}-0.0064 \\
(-0.88) \\
{[-0.0198]}\end{array}$ & $\begin{array}{c}-0.0033 \\
(-1.06) \\
{[-0.0103]}\end{array}$ & $\begin{array}{c}-0.0065 \\
(-0.92) \\
{[-0.0203]}\end{array}$ & $\begin{array}{c}-0.0064 \\
(-0.88) \\
{[-0.0198]}\end{array}$ & $\begin{array}{c}-0.0246 \\
(-0.70) \\
{[-0.0134]}\end{array}$ & $\begin{array}{c}-0.0207 \\
(-1.71) \\
{[-0.0113]}\end{array}$ & $\begin{array}{c}-0.0237 \\
(-0.66) \\
{[-0.0129]}\end{array}$ & $\begin{array}{c}-0.0246 \\
(-0.70) \\
{[-0.0134]}\end{array}$ \\
\hline $\begin{array}{l}\text { Lagged state expenditures } \\
\text { on tobacco control }\end{array}$ & $\begin{array}{c}-0.0010 \\
(-0.18) \\
{[-0.0026]} \\
\end{array}$ & $\begin{array}{c}-0.0014 \\
(-0.52) \\
{[-0.0038]}\end{array}$ & $\begin{array}{c}-0.0012 \\
(-0.22) \\
{[-0.0032]}\end{array}$ & $\begin{array}{c}-0.0010 \\
(-0.18) \\
{[-0.0026]}\end{array}$ & $\begin{array}{c}-0.0038 \\
(-0.13) \\
{[-0.0018]} \\
\end{array}$ & $\begin{array}{c}-0.0173 \\
(-1.58) \\
{[-0.0083]}\end{array}$ & $\begin{array}{c}-0.0024 \\
(-0.08) \\
{[-0.0011]} \\
\end{array}$ & $\begin{array}{c}-0.0038 \\
(-0.13) \\
{[-0.0018]}\end{array}$ \\
\hline $\begin{array}{c}\text { Cumulative state } \\
\text { expenditures on tobacco } \\
\text { control }\end{array}$ & $\begin{array}{c}-0.0007 \\
(-0.57) \\
{[-0.0113]}\end{array}$ & $\begin{array}{c}-0.0002 \\
(-0.43) \\
{[-0.0031]}\end{array}$ & $\begin{array}{c}-0.0008 \\
(-0.61) \\
{[-0.0121]}\end{array}$ & $\begin{array}{c}-0.0007 \\
(-0.57) \\
{[-0.0113]}\end{array}$ & $\begin{array}{c}-0.0031 \\
(-0.40) \\
{[-0.0080]}\end{array}$ & $\begin{array}{c}-0.0025 \\
(-1.16) \\
{[-0.0066]}\end{array}$ & $\begin{array}{c}-0.0028 \\
(-0.36) \\
{[-0.0073]}\end{array}$ & $\begin{array}{c}-0.0031 \\
(-0.40) \\
{[-0.0080]}\end{array}$ \\
\hline
\end{tabular}




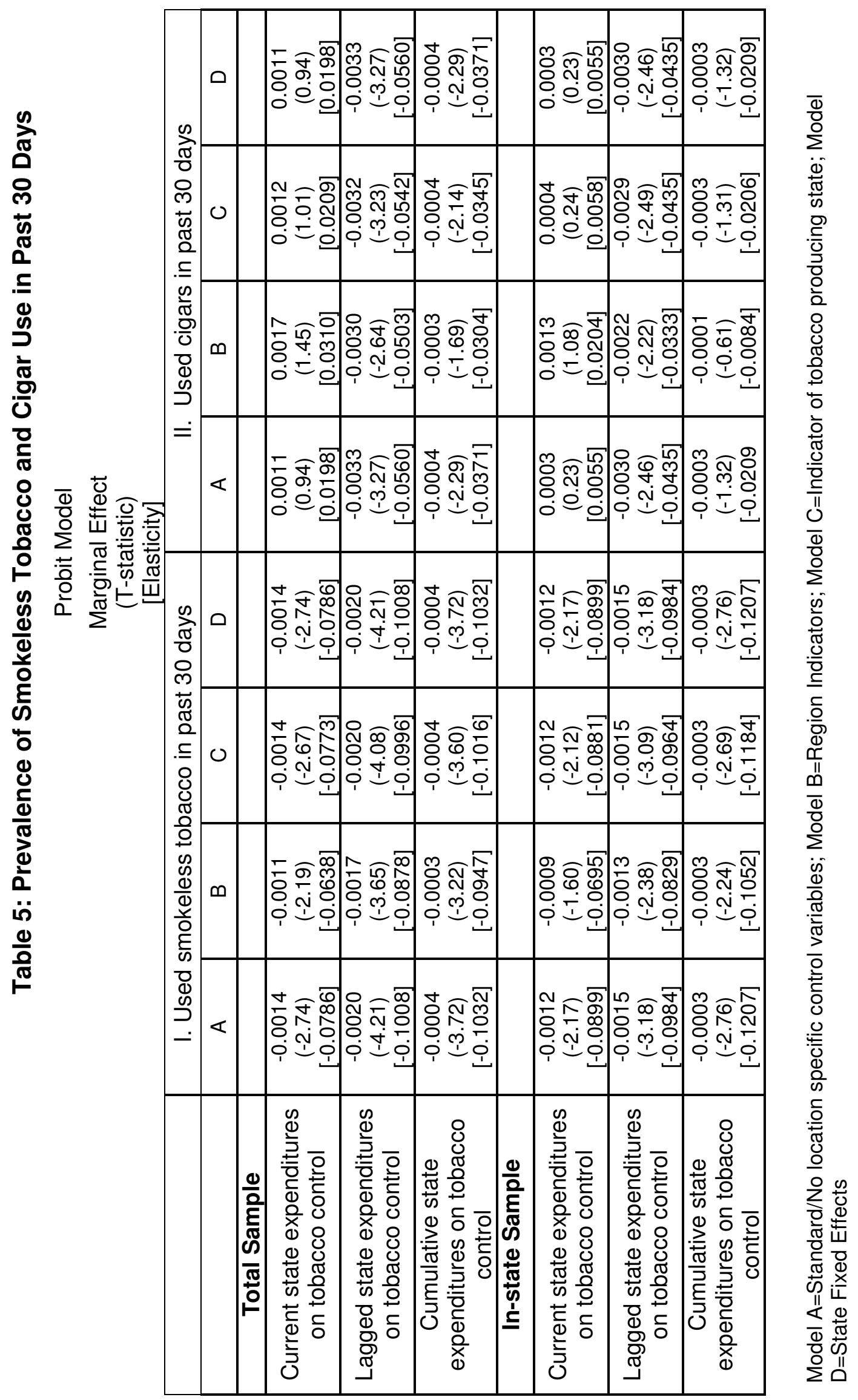


